\title{
Pharmaciana
}

Vol.11, No.3, Nov 2021, Page. 376-384

ISSN: 2088 4559; e-ISSN: 24770256

\section{Formulations of liposomal vaccine containing AdhO36 antigen and $\beta$-glucan as immunoadjuvant}

\author{
Hidajah Rachmawati*1, Raditya Weka Nugraheni' ${ }^{1}$, \\ Firasti Agung Nugrahening Sumadi ${ }^{1}$, Helmy Yusuf ${ }^{2}$ \\ ${ }^{I}$ Department of Pharmacy, Faculty of Health Sciences, University of Muhammadiyah Malang \\ Jl. Bendungan Sutami 188-A, Malang, Indonesia \\ ${ }^{2}$ Department of Pharmaceutics, Faculty of Pharmacy, Airlangga University Surabaya \\ Campus C Mulyorejo, Surabaya, Indonesia
}

\begin{abstract}
Humans are the most crucial host of Salmonella typhi as it has limited ability to reproduce outside the human body. S. typhi infections caused typhoid fever which can be prevented with vaccines. This study aims to develop an effective typhoid fever oral vaccine using a liposomal delivery system. Several studies showed that the immunization of AdhO36 protein from S. typhi orally provides significant protection in inhibiting the $S$. typhi to the mice intestine. $\beta$-Glucan is a potent immunostimulant for macrophages activations. Meanwhile, the method used to produce Liposome formulations was using thin-film hydration. The liposomal products had good characteristics based on their particle size. The particle size results met the requirement for optimum intestinal absorption $399.220 \pm 28.095 \mathrm{~nm}$ Liposome $+\mathrm{AdhO} 36$ and $383.360 \pm 8.594 \mathrm{~nm}$ Liposome $+\beta$-glucan. Based on the zeta potential measurement, the electrical charges of the three formulations were positive, meaning that the liposome is cationic because of the DDAB (dimethyl dioctadecyl ammonium bromide) component. The positive charge will facilitate the internalization of antigen to the immunity cells.
\end{abstract}

Keywords: liposome, AdhO36, $\beta$-glucan, Salmonella typhi, oral vaccine, dimethyl dioctadecyl ammonium bromide (DDAB), cationic liposome

\footnotetext{
*Corresponding author:

Hidajah Rachmawati

Department of Pharmacy, Faculty of Health Sciences, University of Muhammadiyah Malang, Indonesia Campus 2 University of Muhammadiyah Malang

Jl. Bendungan Sutami 188-A, Malang

Email: hidajah@umm.ac.id
} 


\section{INTRODUCTION}

The World Health Organization (WHO) stated that each year an estimated 11 to 21 million illnesses and 128,000 to 161,000 deaths are related to typhoid fever (Gotuzzo, 2018). The increasing cases and relapses show that current treatment methods have not been effective (Ministry of Health, 2006). The resistance worsens the problem to highly used antibiotic drugs and multidrug resistance worldwide (Ugboko and De, 2014). Oral Ty21a vaccine and parenteral Vi capsular polysaccharide (ViCPS) Vaccine are considered as the available, safe, effective, and recommended typhoid fever vaccines based on several clinical trials by CDC (Center for Disease Control and Prevention, USA) (Slayton et al., 2013). The Ty21a used weakened organism and administered orally, which make it is technically easier and caused less pain. However, the attenuated antigen can be virulent to the individual with lower immune responses.

On the other hand, the ViCPS vaccine is an independent T-cell antigen administered parenterally (MacLennan, 2015). Based on the field research, the efficacy was only between $51 \%$ to $67 \%$, while preparations in enteric capsules only had $43 \%$ efficacy (Slayton et al., 2013). Due to the relatively low protection of these products, we still need to develop a new generation of typhoid vaccines.

S. typhi has a fimbria adhesin protein called AdhF36 with type I fimbriae and AdhO36 (afimbrial adhesin). AdhF36 and AdhO36 proteins are proven to be virulent in adhesion and colonization. They have the potential to be immunogenic to stimulate the formation of protective SIgA so that they can become vaccine candidates to prevent the early stages of infection (Kundera et al., 2012). Several studies showed that the immunization of AdhO36 protein from $S$. typhi orally provides significant protection in inhibiting the $S$. typhi to the mice intestine. $\beta$-Glucan is a natural polysaccharide in the cell walls of cereals, bacteria, and fungi with significantly different physicochemical properties depending on the source. $\beta$-Glucan is a potent immunostimulant or a stimulator of cellular immunity activating macrophages. Based on several studies, $\beta$-Glucan has been proven to provide biological effects, for example, the immune potentiation in anti-infection (Vetvicka and Vetvickova, 2007).

Cationic liposomes are widely used in vaccine delivery research because of their efficiency in increasing the immune response. The primary mechanism of DDAB cationic liposomes as an adjuvant is to target APC cell membranes so that they can increase antigen uptake and presentation. (Korsholm et al., 2014) DDAB Liposomes with cationic properties will aggregate after the administration because they interact with proteins in the interstitial space, preventing clearance and giving depot effect. (Perrie et al., 2013) The development of a liposomal vaccine vehicle (VV) with active ingredients AdhO36 and $\beta$-Glucan obtained from Candida albicans' cell wall needs to be further investigated and characterized.

\section{MATERIALS AND METHOD Materials}

S. typhi and C. albicans were obtained from the Laboratory of Microbiology, Medical Faculty, Brawijaya University. Dimethyl dioctadecyl ammonium bromide (DDAB) and cholesterol from Sigma-Aldrich, pro-analytical grade methanol from Merck, Soy-Phosphatidylcholine from Lipoid. The researchers used TEM (JEM 1400) and DLS (Malvern Zeta-sizer) to characterize the liposomal products.

\section{Method \\ Isolation of AdhO36}

S. typhi bacteria propagation temperature on McConkey medium was $37^{\circ} \mathrm{C}$, and the duration was 18-24 hours. After that, this culture was transferred to liquid broth medium and thiaproline, pThe liquid culture was then transferred to the centrifugation tubes while adding TCA (trichloro acetate) until $3 \%$ concentration. Centrifugation was done at $4^{\circ} \mathrm{C}$ at $6000 \mathrm{rpm}$ for 15 minutes. The precipitate was suspended with $\mathrm{pH} 7.4 \mathrm{PBS}$, and the fimbria fraction was separated with a modified pili cutter at 
$4^{\circ} \mathrm{C}$ and centrifuged at $4^{\circ} \mathrm{C}$ with $12000 \mathrm{rpm}$ for 15 minutes. The fimbria was isolated from the sediment and repeated five times. Separated cell fractions were suspended with PBS and added with $5 \%$ concentration CHAPS detergent. The mixture was processed using vortex for 5 minutes and then centrifugated again at $4^{\circ} \mathrm{C}, 12000 \mathrm{rpm}$ for 15 minutes. The filtrate containing crude OMP was dialyzed using pH 7.4 PBS (Santoso, 2018; Winarsih et al., 2017).

\section{Protein Profiling of AdhO36}

The dialysate was electrophoresed using SDS-PAGE. The electrophoregram band at position 36 $\mathrm{kDa}$ was separated from the rest and collected. The gel pieces were electrocuted and dialyzed using Phosphate Buffer Saline (PBS) solution to obtain the uncontaminated AdhO36 protein (Megayasa et al., 2016; Winarsih et al., 2017)

\section{Isolation of $\beta$-glucan from Candida albicans}

The Candida albicans culture was harvested and separated by centrifugation (3000g rpm) using pH 7.4 PBS. The cell pellet was collected and washed five times with lysis buffer. The lysis buffer is prepared by mixing ten $\mathrm{mM}$ Tris- $\mathrm{HCl}$ and $1 \mathrm{mM}$ phenylmethylsulphonyl Fluoride fluoride [PMSF] and then centrifuged at $3000 \times \mathrm{g}$ for 10 minutes. The residue was collected and suspended in lysis buffer at $4^{\circ} \mathrm{C}$ then lysed with $1 \mathrm{~mm}$ glass beads (Omni Mixer Homogenizer) at $6000 \mathrm{x}$ g for 10 minutes. Centrifugation at $3000 \mathrm{x}$ g for 10 minutes was done to separate the cells. The cell wall fraction was obtained in the precipitate.

\section{$\beta$-glucan characterization}

The precipitate was then spray-dried and characterized using FTIR (Fourier Transform Infrared, Panalytical) and SEM (Scanning Electron Microscope, Hitachi). FTIR characterization was performed by comparing samples of isolates with standards. The samples were mixed with $\mathrm{KBr}$ and pressed to form pellets. Furthermore, pellets were measured using FTIR. Morphological testing was carried out using SEM tools. Several samples were placed on the adhesive and support membrane surface, then put on the instrument and observed.

\section{Preparations of liposomal formulations}

The thin-film hydration approach was used to produce liposomes based on liposome formulations with the ovalbumin antigen model (Yusuf et al., 2019). DDAB, SPC (Soy Phosphatydilcholine), and cholesterol were dissolved in $5 \mathrm{~mL}$ methanol during the production procedure. All formulations had the same lipid phase, which consisted of $0.025 \mathrm{~g}$ DDAB, $0.091 \mathrm{~g}$ $\mathrm{SPC}$, and $0.005 \mathrm{~g}$ cholesterol. The organic methanol solvent was then evaporated using a rotary evaporator at $450^{\circ} \mathrm{C}$ for 60 minutes, until a thin coating of lipid phase formed on the round bottom flask's walls. A solution of the active component, either $\beta$ - Glucan or AdhO36 in PBS pH 7.4, was used to hydrate the thin film layer. The dosage of AdhO36 was $100 \mathrm{~g}$ in $1 \mathrm{~mL}$, while the concentration of $\beta$ - Glucan was $300 \mathrm{~g}$. the liposomal suspension was sonicated for 15 minutes to decrease the particle size. Particle Size Analyzer (PSA) and Transmission Electron Microscope (TEM). morphological analyses were used to characterize the liposomal products

\section{Particle Size and Potential Zeta Determination}

Dynamic light scattering (DLS) was used to measure liposome size and polydispersity index (PDI). The Nanosizer ZS (Malvern Instruments) was utilized as the instrument. The zeta potential of liposomes was measured using a Doppler velocimetry laser and a Nanosizer ZS with a universal dip cell after a 10 -fold dilution in water. 


\section{TEM analysis}

Transmission electron microscopy (TEM, JEOL JEM-1400) was used to observe the morphology of the samples. The liquid samples were prepared on a copper grid at room temperature and examined using negative staining.

\section{RESULT AND DISCUSSION}

\section{Protein Profiling of AdhO36 from Salmonella typhi}

Sodium dodecyl sulfate-polyacrylamide gel electrophoresis (SDS-PAGE) is widely employed to produce high-resolution separation of complex combinations in proteins (Nowakowski et al., 2014). Proteins are separated using SDS-PAGE based on their size. After heating under denaturation and reduction conditions, the protein unfolds and is coated with SDS detergent molecules, resulting in a significant negative charge proportional to the length of the polypeptide chain. When negatively charged protein molecules are deposited on the gel matrix and placed in an electric field, they will migrate towards the positively charged electrode and be separated by molecular sieve action (Suvra Roy, 2014).

Figure 1A shows the identification of pilli and outer membrane protein (OMP) fragments containing protein with $36 \mathrm{KDa}$ molecular weight. Furthermore, crude OMP was dialyzed to purify the AdhO36 protein. The dialysate electrophoresis results showed AdhO36 protein (Figure 1B) to be used as an antigen. AdhO36 protein was proven to be virulent in adhesion and colonization. It has the potential to be immunogenic to stimulate the formation of protective $S-\operatorname{Ig} \mathrm{A}$, so it can be the candidate for vaccines to prevent the initial stages of infection (Rachmawati et al., 2019)

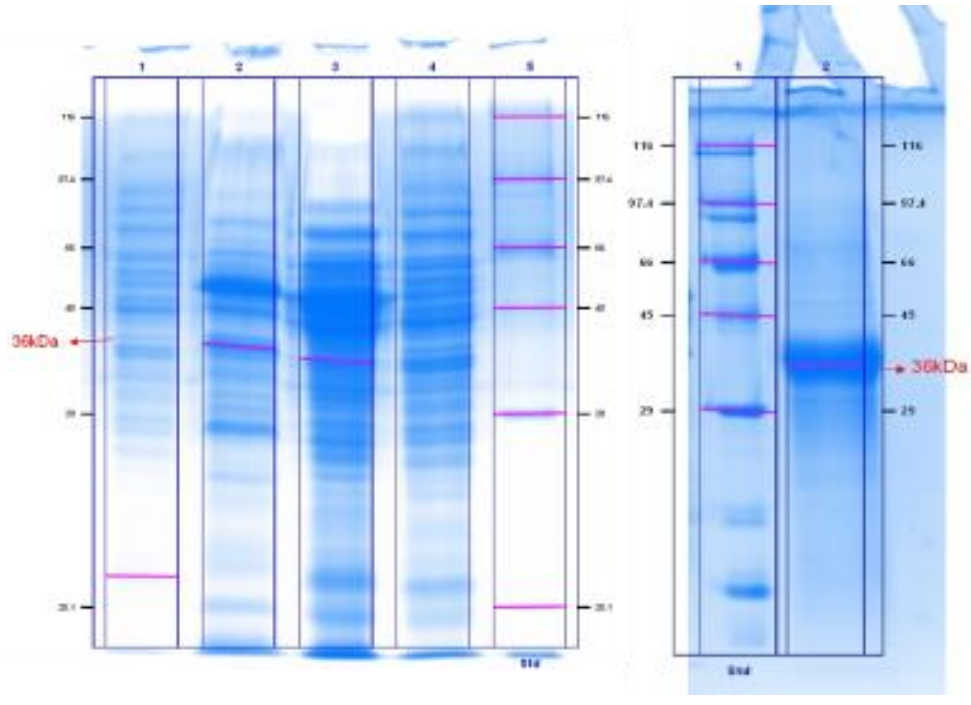

Figure 1. A. Profiling of protein outer membrane protein (OMP) (1. Whole-cell, 2. Pilli, 3. OMP, 4. Whole-cell after pilli cutting, 5. Marker); B. Single-band (1. Marker, 2. OMP)

\section{Characterization of $\beta$-glucan isolated from Candida albicans}

In the standard or sample (Figure 2, Table 1), there were -OH groups or hydrogen bonds, then there were also bonds between $\mathrm{C}-\mathrm{H}$ atoms and $\mathrm{C}-\mathrm{O}-\mathrm{C}$ bonds in the pyranose ring (Novak and Vetvicka, 2008; Wulandari et al., 2016). There were similarities in functional groups between samples isolated from $\mathrm{C}$. albicans with $\beta$-glucan standards indicating the existence of $\beta$-glucan in the model. 


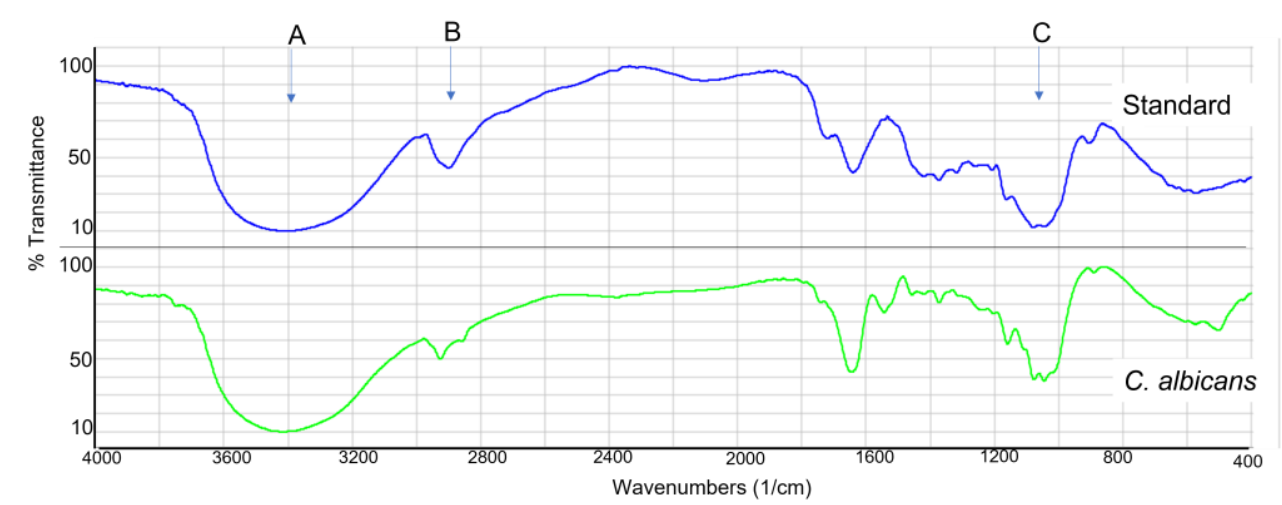

Figure 2. FTIR spectra of $\beta$-Glucan isolated from Candida albicans (Green) compared to the standard (Blue)

Table 1. Functional group analysis of $\beta$-Glucan isolated from Candida albicans (Green) compared to the standard (Blue)

\begin{tabular}{llll}
\hline No & Functional Groups & Standard & Sample \\
\hline A & O-H & 3387 & 3418 \\
B & C-H & 2899 & 2924 \\
C & C-O-C in pyranose ring & 1044 & 1044 \\
\hline
\end{tabular}
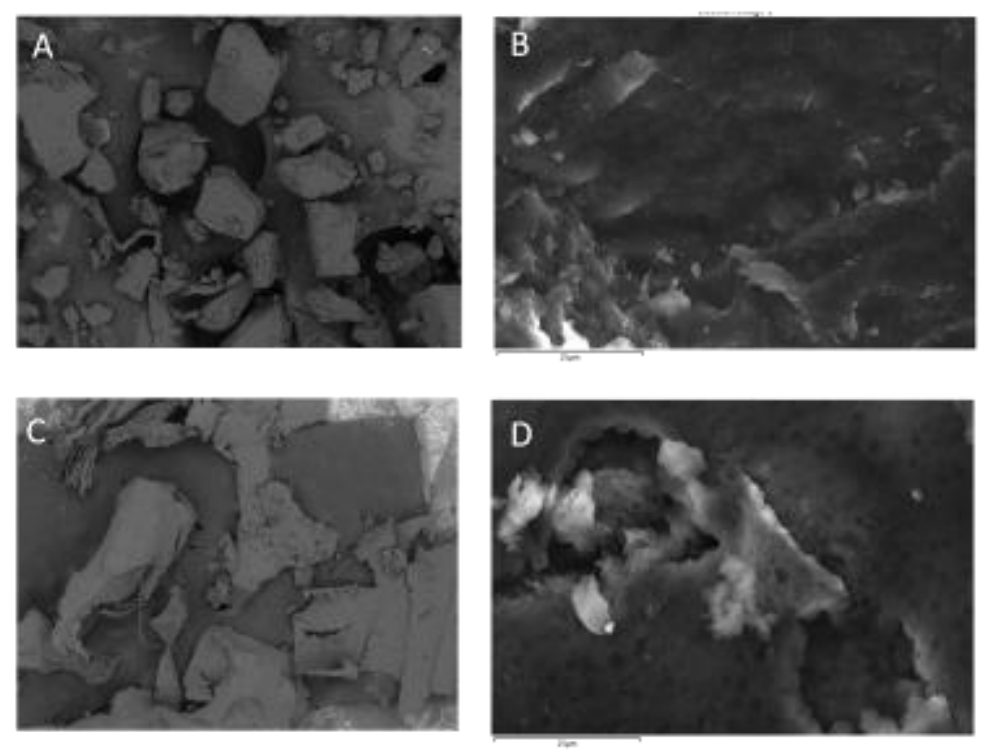

Figure 3. Morphological analysis of standard $\beta$-Glucan (A 250x and B 1500x) and isolated $\beta$ Glucan (B 40x and D 1500x) respectively

Surface analysis with SEM instruments showed uneven surfaces (Figure 3) at the microscopic level caused by the drying process and suspensions containing inhomogeneous cell wall fragments 
during solidification (Novák et al., 2012). These results supported crystallographic analysis with XRD showing that both the sample and standard were amorphous.

\section{Particle size analysis and zeta potential}

The dynamic light scattering method is the most often used for particle size investigation in the nanoscale range. Brownian motion of distributed particles governs Dynamic Light Scattering (DLS). Particles dispersed in a liquid travel in all directions at random. Particles clash with solvent molecules all the time due to Brownian motion. This collision causes a certain amount of energy to be transferred, therefore inducing the movement of particles. The Stokes-Einstein equation explains the relationship between particle velocity and particle size, as the essential requirement for the StokesEinstein equation is the Brownian motion. There will be no random movement if there is sedimentation, which will result in incorrect findings.

Table 2. particle size analysis of liposomal formulations

\begin{tabular}{ccccccc}
\hline \multirow{2}{*}{ Replication } & \multicolumn{2}{c}{ Liposome+AdhO36 } & \multicolumn{2}{c}{ Liposome+ß-glucan } & \multicolumn{2}{c}{ Blank Liposome } \\
\cline { 2 - 7 } & $\begin{array}{c}\text { Particle } \\
\text { Size } \\
(\mathbf{n m})\end{array}$ & $\begin{array}{c}\text { Polydispersity } \\
\text { Index (PdI) }\end{array}$ & $\begin{array}{c}\text { Particle } \\
\text { Size } \\
(\mathbf{n m})\end{array}$ & $\begin{array}{c}\text { Polydispersity } \\
\text { Index (PdI) }\end{array}$ & $\begin{array}{c}\text { Particle } \\
\text { Size } \\
\text { (nm) }\end{array}$ & $\begin{array}{c}\text { Polydispersity } \\
\text { Index (PdI) }\end{array}$ \\
\hline $\mathbf{1}$ & 440.700 & 0.958 & 395.200 & 0.857 & 446.700 & 1.000 \\
$\mathbf{2}$ & 400.600 & 0.872 & 386.800 & 0.647 & 488.100 & 0.938 \\
$\mathbf{3}$ & 388.800 & 0.934 & 371.900 & 0.695 & 520.100 & 0.897 \\
$\mathbf{4}$ & 403.000 & 0.979 & 383.000 & 0.639 & 584.200 & 0.638 \\
$\mathbf{5}$ & 363.000 & 1.000 & 379.900 & 0.797 & 605.500 & 0.552 \\
AVERAGE & 399.220 & 0.949 & 383.360 & 0.727 & 528.920 & 0.805 \\
Standard of & 28.095 & 0.049 & 8.594 & 0.096 & 66.001 & 0.198 \\
Deviation & & & & & & \\
\hline
\end{tabular}

Particle size affects the per-oral bioavailability of the formulations. The smaller the liposome size, the more effective it is in increasing the oral bioavailability of the active ingredient delivered up to three times higher than the larger-sized formulations. This study provided results following the expected specifications, $400 \mathrm{~nm}$ (Table 2) because further downsizing to $\leq 400 \mathrm{~nm}$ did not increase the uptake (Ong et al., 2016). The results met the particle size requirement for optimum intestinal absorption, namely $399.220+28.095 \mathrm{~nm}$ Liposome + AdhO36 and $383.360+8.594 \mathrm{~nm}$ Liposome $+\beta-$ glucan.

Zeta potential is an electrical charge at the interface surface of a solid or colloidal surface with its liquid medium measured in millivolts $(\mathrm{mV})$. Zeta potential shows the potential difference between the dispersing medium and the stationary layer of liquid that surrounds the dispersed particles. The zeta potential measurement is the easiest and most straightforward way to directly characterize the charge on the colloidal surface (Honary and Zahir, 2013). Particle surface charge is crucial in determining the efficiency of particle transmission into cells because it can determine the interaction process with negatively charged cell membranes and initiate endocytosis. Furthermore, the releasing process of particles from the endo lysosome is also influenced by the surface charge of particles (Sumadi, 2020). 
Table 3. Zeta potential and conductivity analysis of liposomal formulations

\begin{tabular}{|c|c|c|c|c|c|c|}
\hline \multirow[t]{2}{*}{ Replication } & \multicolumn{2}{|c|}{ Liposome+AdhO36 } & \multicolumn{2}{|c|}{ Liposome+ $\beta$-glucan } & \multicolumn{2}{|c|}{ Blank Liposome } \\
\hline & $\begin{array}{c}\text { Zeta } \\
\text { Potential } \\
(\mathbf{m V})\end{array}$ & $\begin{array}{l}\text { Conductivity } \\
(\mathrm{mS} / \mathrm{cm})\end{array}$ & $\begin{array}{c}\text { Zeta } \\
\text { Potential } \\
(\mathrm{mV})\end{array}$ & $\begin{array}{c}\text { Conducti- } \\
\text { vity } \\
(\mathrm{mS} / \mathrm{cm})\end{array}$ & $\begin{array}{c}\text { Zeta } \\
\text { Potential } \\
(\mathrm{mV})\end{array}$ & $\begin{array}{c}\text { Conducti- } \\
\text { vity } \\
(\mathrm{mS} / \mathrm{cm})\end{array}$ \\
\hline 1 & 7.52 & 14.50 & 20.70 & 13.60 & 20.50 & 11.50 \\
\hline 2 & 6.13 & 16.10 & 22.30 & 14.90 & 24.30 & 14.20 \\
\hline 3 & 7.83 & 16.30 & 16.70 & 15.10 & 21.60 & 14.50 \\
\hline 4 & 5.78 & 16.40 & 17.60 & 15.30 & 26.70 & 14.70 \\
\hline 5 & 7.18 & 16.40 & 18.60 & 15.50 & 26.80 & 14.80 \\
\hline Average & 6.89 & 15.94 & 19.18 & 14.88 & 23.98 & 13.94 \\
\hline $\begin{array}{c}\text { Standard of } \\
\text { Deviation }\end{array}$ & 0.89 & 0.81 & 2.29 & 0.75 & 2.88 & 1.38 \\
\hline
\end{tabular}

Based on Table 3, it can be seen that the zeta potential for the three formulations had a positive value, meaning that this liposome was cationic as a result of the DDAB component (Giddam et al., 2012). However, there was a decrease in the charge from the Liposome Blank (VV) $(+23.98 \pm 2.88)$ $\mathrm{mV}$ compared to $\mathrm{VV}+$ Adho36 $(+6.89 \pm 0.89) \mathrm{mV}$. This result is presumably because the AdhO36 protein is naturally negatively charged. Thus, reducing the potential difference. However, because it was cationic, it can still facilitate the delivery of antigens into APC (Antigen Presenting Cell) cells, increasing the immune responses (Baxa, 2018). The physical properties of the liposome system, significantly the charge and fluidity of the bilayer membrane, are mainly determined by the composition of the lipid bilayer. The physical stability of DDAB is low because it is aggregated quickly in salty liquids, even at low concentrations (Nugraheni et al., 2020). Our previous studies showed the effectiveness of the combination between liposomes containing $\beta$-Glucan from $C$. albicans and AdhO36 S. typhi, which potentially affects cellular and humoral immune response (Rachmawati et al., 2020).

\section{Morphological analysis}

Transmission electron microscopy (TEM) is a method that creates an image by passing electron beams through a material. The specimen was made very thin with a less than $100 \mathrm{~nm}$ thickness or a lattice suspension. The image was formed from the interaction of electrons with the sample when the beam was transmitted through the specimen. TEM is an essential method for characterizing the size and shape of nanoparticles because it can directly visualize a single particle and its inner structure.
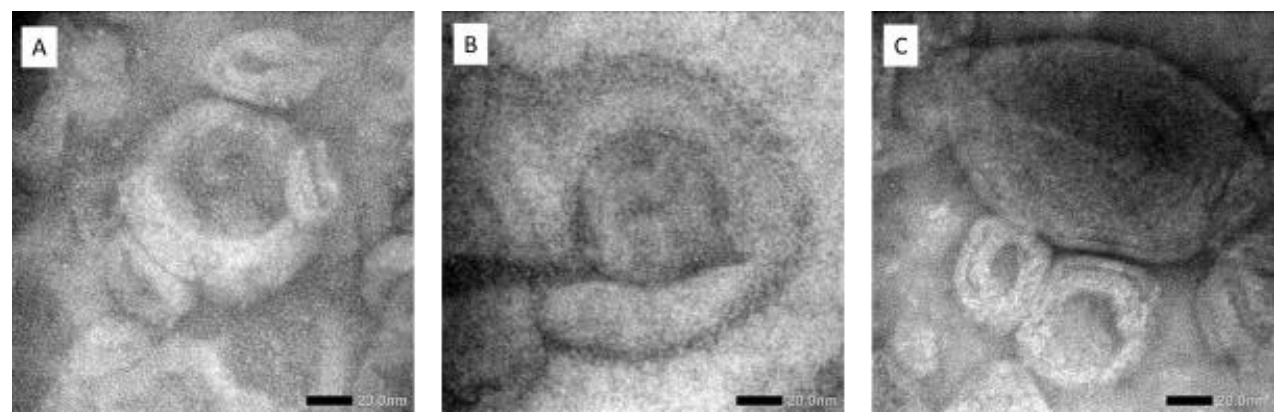

Figure 4. TEM imaging of liposomal formulations: A. Liposome+AdhO36; B. Liposome+ $+\beta-$ glucan; C. Blank Liposome. Magnitude 200.000x 
Imaging results with the TEM instrument showed that liposomes were spherical in shape (Figure 4). The phospholipid bilayer membrane was multilamellar or had several layers indicated by red arrows. This multilamellar wall serves to release antigens slowly or gradually (Agnihotri et al., 2010).

\section{CONCLUSION}

It can be concluded that the AdhO36 protein and $\beta$-glucans have the potential to be developed into liposomal dosage forms and can be given orally due to their small particle size.

\section{ACKNOWLEDGEMENT}

The authors thank the authorities, Muhammadiyah Malang University, especially Brawijaya University School of Medicine and Health Science, for their technical support in conducting the research.

\section{REFERENCES}

Agnihotri, S. A., Soppimath, K. S., \& B-geri, G. V. (2010). Controlled release application of multilamellar vesicles: A novel drug delivery approach. Drug Delivery, 17(2), 92-101. https://doi.org/10.3109/10717540903509027

Baxa, U. (2018). Imaging of Liposomes by transmission electron microscopy. In S. E. McNeil (Ed.), Characterization of Nanoparticles Intended for Drug Delivery (Vol. 1682, pp. 73-88). Springer New York. https://doi.org/10.1007/978-1-4939-7352-1 8

Giddam, A. K., Zaman, M., Skwarczynski, M., \& Toth, I. (2012). Liposome-based delivery system for vaccine candidates: Constructing an effective formulations. Nanomedicine, 7(12), 1877-1893. https://doi.org/10.2217/nnm.12.157

Gotuzzo, E. (2018). Typhoid fever: A current problem. International Journal of Infectious Diseases, 73, 46-47. https://doi.org/10.1016/j.ijid.2018.04.3528

Honary, S., \& Zahir, F. (2013). Effect of zeta potential on the properties of nano-drug delivery systems - a review (Part 1). Tropical Journal of Pharmaceutical Research, 12(2), 255-264-264. https://doi.org/10.4314/tjpr.v12i2.19

Korsholm, K. S., Hansen, J., Karlsen, K., Filskov, J., Mikkelsen, M., Lindenstrøm, T., Schmidt, S. T., Andersen, P., \& Christensen, D. (2014). Induction of CD8+ T-cell responses against subunit antigens by the novel cationic liposomal CAF09 adjuvant. Vaccine, 32(31), 3927-3935. https://doi.org/10.1016/j.vaccine.2014.05.050

Kundera, I. N., Santoso, S., A, A., \& Winarsih, S. (2012). Ekspresi protein ADHF36 Pada perubahan osmolaritas serta $\mathrm{pH}$ lingkungan hidup Salmonella Typhi secara in vitro. Jurnal Kedokteran Hewan - Indonesian Journal of Veterinary Sciences, 6(1).

MacLennan, C. A. (2015). Global health vaccines against the invasive Salmonelloses: enteric fever and invasive non-typhoidal Salmonella. Advanced Vaccine Research Methods for the Decade of Vaccines, 387. https://doi.org/10.21775/9781910190036.16

Megayasa, N. A., Winarsih, S., \& Santoso, S. (2016). Reaksi silang antara antibodi Adho36 Salmonella Typhi dengan outer membrane protein vibrio cholerae menggunakan metode Western Blotting. Majalah Kesehatan FKUB, 1(1), 16-23

Novák, M., Synytsya, A., Gedeon, O., Slepička, P., Procházka, V., Synytsya, A., Blahovec, J., Hejlová, A., \& Čopíková, J. (2012). Yeast $\beta(1-3),(1-6)$-d-glucan films: Preparation and characterization of some structural and physical properties. Carbohydrate Polymers, 87(4), 2496-2504. https://doi.org/10.1016/j.carbpol.2011.11.031

Novak, M., \& Vetvicka, V. (2008). $\beta$-Glucans, History, and the Present: immunomodulatory aspects and mechanisms of action. Journal of Immunotoxicology, 5(1), 47-57. https://doi.org/10.1080/15476910802019045

Nowakowski, A. B., Wobig, W. J., \& Petering, D. H. (2014). Native SDS-PAGE: High Resolution electrophoretic separation of proteins with retention of native properties including bound metal 
ions. Metallomics: Integrated Biometal Science, 6(5), 1068-1078. https://doi.org/10.1039/c4mt00033a

Nugraheni, R. W., Yusuf, H., \& Mulyadi, N. A. (2020). Freeze-dried liposome formulations for small molecules, nucleic acid, and protein delivery. Systematic Reviews in Pharmacy, 11(7), 143-151

Ong, S. G. M., Ming, L. C., Lee, K. S., \& Yuen, K. H. (2016). Influence of the encapsulation efficiency and size of liposome on the oral bioavailability of griseofulvin-loaded liposomes. Pharmaceutics, 8(3). https://doi.org/10.3390/pharmaceutics8030025

Perrie, Y., Kastner, E., Kaur, R., Wilkinson, A., \& Ingham, A. J. (2013). A case-study investigating the physicochemical characteristics that dictate the function of a liposomal adjuvant. Human Vaccines \& Immunotherapeutics, 9(6), 1374-1381. https://doi.org/10.4161/hv.24694

Rachmawati, H., Sumarno, H. K., Barlianto, W., Sardjono, T. W., Endharti, A. T., \& Winarsih, S. (2019). In Silico approach: B-Glucan and AdhO36 combinations enhance the Th1 immune response against Salmonella Typhi infection

Rachmawati, H., Winarsih, S., Prawiro, S. R., Barlianto, W., Santoso, S., Djunaedi, D., Endharti, A. T., Sardjono, T. W., Khotimah, H., Prihanti, G. S., Nugraheni, R. W., Sumadi, F. A. N., \& Yusuf, H. (2020). AdhO36 liposomes from Salmonella Typhi in combination with $\beta$-Glucan Immuno-adjuvant From Candida albicans cell wall as oral vaccine against typhoid fever in mice model. Open Access Macedonian Journal of Medical Sciences, 8(A), 441-448. https://doi.org/10.3889/oamjms.2020.4422

Santoso, S. (2018). Adhesion test of hemagglutinin-O36 Protein of Salmonella Typhi Malang isolate at Balb/C Mice Enterocytes. Jurnal Kedokteran Brawijaya, 18(2), 51-59

Slayton, R., Date, K., \& Mintz, E. (2013). Vaccination for typhoid fever in Sub-Saharan Africa. Human Vaccines \& Immunotherapeutics, 9(4), 903-906. https://doi.org/10.4161/hv.23007

Sumadi, F. A. N. (2020). Kitosan Teradiasi Gamma 5 kGy mempengaruhi muatan permukaan Nanopartikel MikroRNA. Journal of Herbal, Clinical and Pharmaceutical Science (HERCLIPS), 1(02), 20-23. https://doi.org/10.30587/herclips.v1i02.1412

Suvra Roy, V. K. (2014). A practical approach on sds page for separation of protein. International Journal of Science and Research (IJSR), 3(8), 955-960. https://doi.org/10.12988/astp.2014.48109

Ugboko, H., \& De, N. (2014). De, N. Mechanisms of Antibiotic resistance in Salmonella typhi. International Journal of Current Microbiology and Applied Science, 3(12), 461-76

Vetvicka, V., \& Vetvickova, J. (2007). Physiological effects of different types of $\beta$-glucan. Biomedical Papers of the Medical Faculty of Palacky University in Olomouc, 151(2). https://doi.org/10.5507/bp.2007.038

Winarsih, S., Sujuti, H., \& Yasmin, A. (2017). Pengaruh kadar glukosa terhadap ekspresi protein Adho36 bakteri Salmonella Typhi. Majalah Kesehatan FKUB, 4(3), 105-113. https://doi.org/10.21776/ub.majalahkesehatan.2017.004.03.1

Wulandari, W. T., Rochliadi, A., \& Arcana, I. M. (2016). Nanocellulose prepared by acid hydrolysis of isolated cellulose from sugarcane bagasse. IOP Conference Series: Materials Science and Engineering, 107, 012045. https://doi.org/10.1088/1757-899X/107/1/012045

Yusuf, H., Nugraheni, R. W., \& Setyawan, D. (2019). Effect of cellulose derivative matrix and oligosaccharide on the solid state and physical characteristics of dimethyldioctadecylammonium-liposomes for vaccine. Research in Pharmaceutical Sciences, 14(1), 1-11. https://doi.org/10.4103/1735-5362.251847 